\title{
Assessment of flash floods taking into account climate change scenarios in the Llobregat River basin
}

\author{
M. Velasco ${ }^{1}$, P. A. Versini ${ }^{2,}$, A. Cabello ${ }^{1}$, and A. Barrera-Escoda ${ }^{3}$ \\ ${ }^{1}$ CETaqua Water Technology Centre, Barcelona, Spain \\ ${ }^{2}$ CRAHI, Research Centre of Applied Hydrometeorology, Barcelona, Spain \\ ${ }^{3}$ SMC, Meteorological Service of Catalonia, Barcelona, Spain \\ *now at: ENPC, France
}

Correspondence to: M. Velasco (mvelasco@cetaqua.com)

Received: 2 August 2012 - Published in Nat. Hazards Earth Syst. Sci. Discuss.: -

Revised: 13 September 2013 - Accepted: 22 October 2013 - Published: 6 December 2013

\begin{abstract}
Global change may imply important changes in the future occurrence and intensity of extreme events. Climate scenarios characterizing these plausible changes were previously obtained for the Llobregat River basin (NE Spain). This paper presents the implementation of these scenarios in the HBV (Hydrologiska Byråns Vattenbalansavdelning) hydrological model. Then, the expected changes in terms of flash flood occurrence and intensity are assessed for two different sub-basins: the Alt Llobregat and the Anoia (Llobregat River basin).

The assessment of future flash floods has been done in terms of the intensity and occurrence of extreme events, using a peak over threshold (POT) analysis. For these two subbasins, most of the simulated scenarios present an increase of the intensity of the peak discharge values. On the other hand, the future occurrence follows different trends in the two sub-basins: an increase is observed in Alt Llobregat but a decrease occurs in Anoia. Despite the uncertainties that appear in the whole process, the results obtained can shed some light on how future flash floods events may occur.
\end{abstract}

\section{Introduction}

Flash floods are caused by an intense rain event producing several hundreds of $\mathrm{mm}$ in a few hours (Collier, 2007; Younis et al., 2008; Versini, 2012). Such events typically occur in quick response basins characterized by (i) the small size of the catchments (under few hundreds $\mathrm{km}^{2}$ ), and (ii) flood flows that are essentially composed of surface runoff water or at least fast responding runoff processes (Creutin et al., 2009). In Marchi et al. (2010), the response times of several European flash flood events were studied. In 37 out of 50 cases, lag time was shorter than $6 \mathrm{~h}$, the average response time being $4.98 \mathrm{~h}$. Hence, it is very difficult to issue accurate warnings for these events in real time.

Flash floods are very destructive natural hazards both in economic terms and regarding loss of life (Llasat et al., 2003; Gaume et al., 2004). Gaume et al. (2009) undertook a first initiative to develop an inventory of such events in Europe. From the more than 550 documented events, several conclusions were drawn. For example, the magnitude of European flash floods is more extreme in Mediterranean regions than in inland continental regions and flash floods often result in loss of life (which is not that common in lowland floods).

Some researchers have found that extreme events are expected to increase all over Europe due to global change (Dankers and Feyen, 2009). However, there is not a lot of agreement in concluding that the occurrence and magnitude of floods have increased due to climate-driven changes (Intergovernmental Panel on Climate Change (IPCC), 2012). The main problem is that there is not enough evidence because instrumental records are limited and not widespread.

Nevertheless, several studies project increases in heavy rainfall in some regions. In Catalonia, the northeast of Spain, studies of the regional climate conditions already show that some changes have been occurring since the 1950s (Turco and Llasat, 2011). Therefore, physical reasoning suggests that increases in local floods might occur in these situations (Kundzewicz et al., 2007). 
Given all the uncertainties that surround future projections of floods (see IPCC (2012) for a thorough description), Kundzewicz (2012) recommends the undertaking of studies at lower scales in order to properly assess the spatial variability regarding future flood risk.

As reviewed by IPCC (2012), there are already a few studies regarding flood magnitude and occurrence changes at river basin level. Scientific literature on these issues is mainly focused on continental Europe (van Pelt et al., 2009), the UK (Kay et al., 2009) and North America (Raff et al., 2009).

Given that the current climate conditions in the Mediterranean strongly differ from these areas, and that the future projections may also be very different, this study aims to assess the future flood trends in an area that has not been deeply studied. Thus, this work presents the results of an assessment of future flood magnitude and frequency in the Llobregat River basin (Spain).

The paper is structured as follows: Sect. 2 describes the test basins; in Sect. 3, the methodology used is described; Sect. 4 presents the data used in this study; in Sect. 5, the results of applying this methodology in the Llobregat River basin can be found; Sect. 6 is a short discussion of the uncertainties present in the study; and the general conclusions of the paper are summarized in Sect. 7.

\section{Case study and data}

The eastern part of Catalonia, located in the northeast of Spain, has all the specific characteristics to develop severe flash floods: Mediterranean climate, small watersheds with steep slopes and an orography that creates intense convective precipitation events (Llasat et al., 2003, 2005). Therefore, flash flood events often occur, presenting in many cases catastrophic consequences due to the human developments that have been built around the rivers. For example, in the Llobregat River basin there was an event in 1962 with over 400 deaths (López Bustos, 1964), and the event that occurred in Montserrat on 10 June 2000 caused material damage of approximately EUR 65 million, as well as five casualties (Llasat et al., 2003).

\subsection{Llobregat River basin}

The Llobregat River basin is located in Catalonia, in the northeastern part of the Iberian Peninsula. It covers a total area of more than $5000 \mathrm{~km}^{2}$ and its elevation ranges from sea level up to $1259 \mathrm{~m}$ (Fig. 1). The River Llobregat, which is $156.6 \mathrm{~km}$ long, takes its source in the Pyrenees Mountains. Its main tributaries are Cardener and Anoia on the west side, and Gavarresa and Rubí on the east side.

It crosses quite densely populated areas and ends in the Mediterranean Sea. The river usually flows through an irregular terrain, and at its last stretch it forms a delta, which is currently one of the most urbanized and industri-

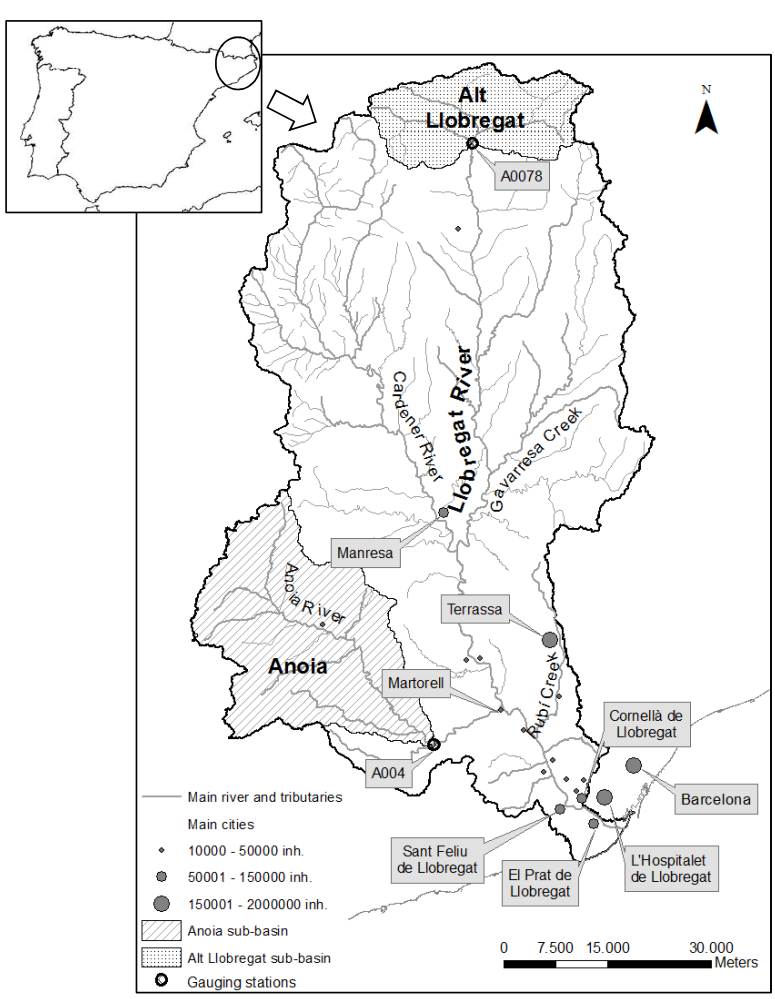

Fig. 1. Location of the Llobregat River basin.

ally developed areas of the region. The Llobregat River is the most important drinking water source for Barcelona and its surrounding area. It represents a water supply source for up to 1300000 inhabitants, who use it for drinking, agricultural irrigation, industry and hydroelectric energy production.

The Llobregat River is highly dependent on climatic conditions. It has a low mean annual discharge (around $20 \mathrm{~m}^{3} \mathrm{~s}^{-1}$ ) with flow peaks that often reach values 100 times greater than the base flow (Thorndycraft et al., 2005). That is why flood events are frequently produced. In the period between 1315 and 2002, the Llobregat River has had 171 floods at its mouth, and 39 of them had catastrophic effects (Llasat et al., 2005).

Mean annual rainfall in the catchment varies from 900 to $1100 \mathrm{~mm}$ in the headwater reaches and from 500 to $700 \mathrm{~mm}$ in the middle and lower reaches. However, large flood events are triggered by maximum rainfall exceeding at least $200 \mathrm{~mm}$ within a $24 \mathrm{~h}$ period. The majority of the largest floods over the last century occurred in autumn. They are associated with a synoptic pattern of anticyclonic conditions over $\mathrm{Eu}-$ rope and warm, moist air coming from the southeast that causes intense orographic rainfall over the coastal and prePyrenean mountains (Thorndycraft et al., 2005; Llasat et al., 2003). Due to its exposition to heavy rains and flooding, hydrological research is an issue of major social interest in Catalonia (Martín-Vide et al., 1999). 


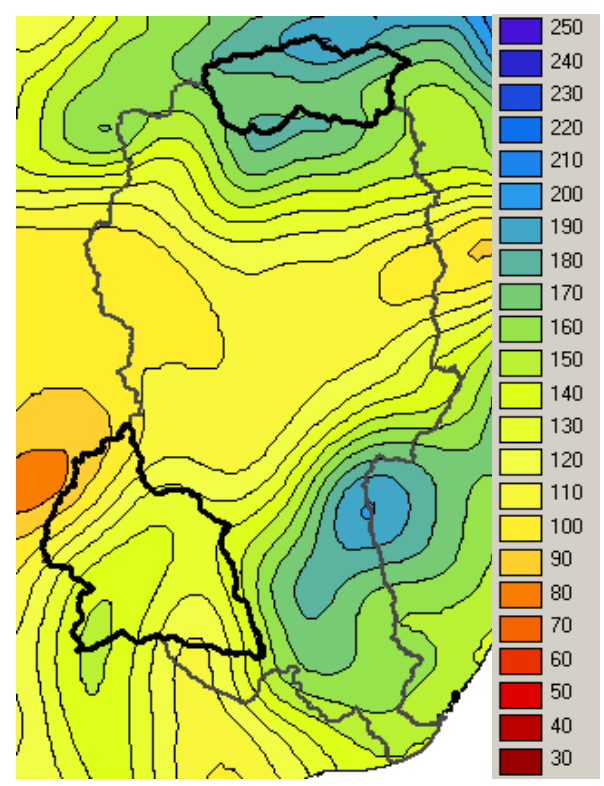

Fig. 2. Daily maximum precipitation (in $\mathrm{mm}$ ) for a $100 \mathrm{yr}$ return period, showing the Llobregat, Alt Llobregat and Anoia basins. Source: Casas et al. (2005).

This study has been implemented in two gauged subbasins of the Llobregat River, in order to see the impacts in two geographically different areas (Fig. 1): the Alt Llobregat sub-basin $\left(333 \mathrm{~km}^{2}\right)$ and the Anoia sub-basin $\left(732 \mathrm{~km}^{2}\right)$.

\subsubsection{Alt Llobregat sub-basin}

The Alt Llobregat sub-basin, located in the Pyrenees area, is a sparsely populated area, with less than 30 inhabitants (inh) per $\mathrm{km}^{2}$. Due to its location, the annual rainfall is the highest in the whole basin, and the temperatures are low, with an annual average around $10^{\circ} \mathrm{C}$. As can be seen in Fig. 2, the daily maximum precipitation rates for a $100 \mathrm{yr}$ return period are high, ranging between 160 and $200 \mathrm{~mm}$ (Casas et al., 2005). The mean annual flow in the Guardiola de Berguedà river gauge (code A0078) is $4 \mathrm{~m}^{3} \mathrm{~s}^{-1}$.

\subsubsection{Anoia sub-basin}

In the Anoia basin, located in the pre-coastal mountains, the annual rainfall is generally around $600 \mathrm{~mm}$, and the annual average temperature is around $13^{\circ} \mathrm{C}$. Since it is closer to the metropolitan area of Barcelona, it is a rather densely populated area, with a density of around $125 \mathrm{inh}$ per $\mathrm{km}^{2}$. In Fig. 2, it can be seen that the daily maximum precipitation ranges from 90 to $150 \mathrm{~mm}$ for a $100 \mathrm{yr}$ return period, which is a rather low value compared to the Alt Llobregat. Its annual average flow presents a value of $1 \mathrm{~m}^{3} \mathrm{~s}^{-1}$ in the Sant Sadurní d'Anoia river gauge (code A004).

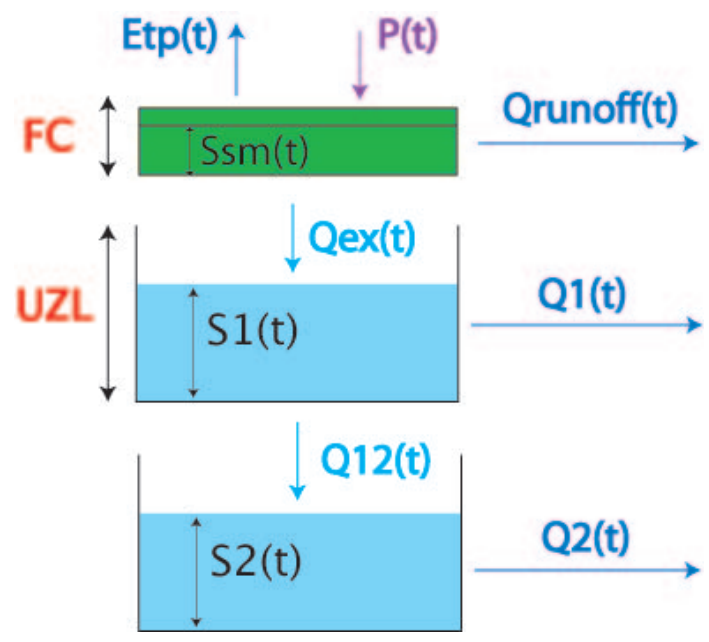

Fig. 3. Configuration of the HBV model at the sub-basin scale.

\section{Methodology}

To assess the impact of climate change in flash flood events, a methodology with several steps must be followed. First of all, an implementation of the future climate change scenarios in the HBV (Hydrologiska Byråns Vattenbalansavdelning) hydrological model must be done. Then, using the peak over threshold (POT) approach and fitting a generalized Pareto (GP) distribution, the occurrence and intensity of future flash floods can be assessed.

\subsection{HBV hydrological model}

The HBV rainfall-runoff model (Bergström, 1992) has been used to simulate past and future discharge time series in the Llobregat basin at the daily timescale. In different model versions, HBV has been applied in more than 40 countries all over the world (Jin et al., 2009; Lidén and Harlin, 2000; Zhang and Lindström, 1997). It has also been used in several climate change studies to estimate future discharge modifications (Akhtar et al., 2008; Leander and Buishand, 2007; Merritt et al., 2006; Steele-Dunne et al., 2008). HBV is commonly used as a semi-distributed model by dividing the catchment into sub-watersheds and running on daily rainfall and air temperature values.

At the sub-basin scale, the HBV model is divided into several routines, depending on the process to be represented: direct runoff, soil moisture, upper and lower reservoir filling and emptying, and flow transfer (as represented in Fig. 3 and detailed in the following sections). Note that for the sake of understanding, discharge and water level are all expressed in $\mathrm{mm} /$ day. 


\subsubsection{Direct runoff}

An extra discharge representing the direct runoff has been added to the original version of the HBV model. The objective of adding this direct runoff corresponds to the specific Mediterranean climatological and geographical properties where intense rainfall falls on impervious rock, generating high runoff. Direct runoff $\left[Q_{\text {runoff }}(t)\right]$ is produced when the water contained in the upper soil layer $\left[S_{\mathrm{sm}}(t)\right]$ exceeds the soil saturation threshold (FC). Similar changes were made by Uhlenbrook and Sieber (2005) and Götzinger and Bárdossy (2007). It is conducted by the following equations:

$Q_{\text {runoff }}(t)=S_{\mathrm{sm}}(t)-\mathrm{FC}$ if $S_{\mathrm{sm}}(t)>\mathrm{FC}$

$Q_{\text {runoff }}(t)=0$ if $S_{\mathrm{sm}}(t)<\mathrm{FC}$.

\subsubsection{Soil moisture to calculate excess water from the soil and evapotranspiration}

Excess water from the soil $\left[Q_{\mathrm{ex}}(t)\right]$ is calculated from the weighted precipitation $P(t)$ using a nonlinear relationship between soil moisture storage, soil saturation threshold (FC), and an empirical parameter $\beta$, as given in Eq. (2). Small contributions of excess water from the soil result from dry soil and larger contributions for wet conditions.

$Q_{\mathrm{ex}}(t)=\left(\frac{S_{\mathrm{sm}}(t)}{\mathrm{FC}}\right)^{\beta} \times P(t)$.

Daily potential evapotranspiration $\left[E_{\mathrm{tp}}(t)\right]$ computed by using the Thornthwaite formula is subtracted at each time step from the soil layer.

\subsubsection{Upper and lower reservoirs: discharge generation}

The discharge generation routine is the response function that transforms excess water from the soil moisture storage $\left[Q_{\text {ex }}(\mathrm{t})\right]$ to discharge. This response function is represented by an upper nonlinear reservoir and a lower linear reservoir. These reservoirs represent respectively the response of the subsurface $[Q 1(t)]$ and the base flow $[Q 2(t)]$. Both discharges are conducted by Eqs. (3)-(5):

$$
\begin{aligned}
& Q 1(t)= \\
& \left\{\begin{array}{l}
K 1 \times\left(S 1(t)+Q_{\mathrm{ex}}(t)\right) \text { if }\left(S 1(t)-Q_{\mathrm{ex}}(t)\right) \leq \mathrm{UZL} \\
(K 1+K 0) \times\left(S 1(t)-Q_{\mathrm{ex}}(t)\right)-K 0 \times \mathrm{UZL} \\
\text { if }\left(S 1(t)-Q_{\mathrm{ex}}(t)\right)>\mathrm{UZL}
\end{array}\right. \\
& Q 12(t)=\operatorname{Perc} \times S 1(t) \\
& Q 2(t)=K 2 \times(S 1(t)+Q 12(t))
\end{aligned}
$$

where $K 0, K 1, K 2$ are the recession coefficients (fraction value between 0 and 1$)$, UZL is the maximum level of the upper reservoir, $Q 12(t)$ is the percolation rate between both reservoirs conducted by parameter Perc, $S 1(t)$ is the storage in the upper response reservoir, and $S 2(t)$ is the storage in the lower response reservoir.

\subsubsection{Total discharge and routing}

The total discharge is calculated as the sum of the different discharge components: direct runoff $\left[Q_{\text {runoff }}(t)\right]$, subsurface discharge $[Q 1(t)]$, and base flow $[Q 2(t)]$. As both studied basins are quite small $\left(333 \mathrm{~km}^{2}\right.$ for Alt Llobregat and 732 $\mathrm{km}^{2}$ for Anoia) regarding the timescale, no routing function has been added. The total discharge is directly routed to the outlet:

$Q_{\operatorname{sim}}(t)=Q 1(t)+Q 2(t)+Q_{\text {runoff }}(t)$.

Finally, reservoirs are updated by taking into account the different inputs and outputs at the end of each time step.

\subsection{Flood frequency analysis}

The frequency analysis of future flash floods from this study is done by using a method called peak over threshold (POT) (Todorovic, 1978), which consists in retaining all peak values that exceed a certain threshold. Compared to the annual maximum flood method (AMF), POT modelling provides a more complete description of the flood generating process because more than one event per year can be selected (Lang et al., 1999). Therefore, POT methodology takes into account a wider range of extreme precipitation values and provides the possibility to control the number of occurrences to be included in the analysis by the appropriate selection of the threshold.

Since the POT approach is not confined to only one event per year, this methodology allows one to capture more information concerning the whole flood phenomena. This methodology was previously applied to the Llobregat River basin (Barriendos et al., 2003), observing that this basin presents a complex time process, with some periods presenting large floods and other periods without such events.

However, problems with definition of a threshold and criteria selection for including flood peaks represent some of the main difficulties associated with the POT approach. These two elements are of great importance for satisfying the model hypotheses concerning the independence and distribution of flood peaks. Lang et al. (1999) proposed a set of practiceoriented guidelines in order to solve these problems.

Previous to the threshold definition, it is required to assess the independence of the peaks considered for the analysis. Assuming that the exceedances are independent, identically distributed random variables, these values can be represented by the GP distribution (Coles, 2001). 
There have been several attempts to define independence criteria (Lang et al., 1999). Nevertheless, due to the difficulty of using physical arguments to define the dependence between two events, the methodology defined by Miquel (1984) is the one that will be used in this study. This approach does not impose a minimum value for the interevent duration. On the other hand, it requires that the autocorrelation of the peak values is assumed to be null for the lag 1 and lag 2 cases (which imply a delay of 1 and 2 days when performing the correlation of a data series with itself). If the hypothesis of a null autocorrelation is not accepted, the process must be repeated using a larger value of interevent duration.

Regarding the selection of an adequate threshold, several methodologies exist, depending on the purpose of the study and the characteristics of the data available. Whereas in some cases the truncation value is chosen using physical criteria (e.g. overflow level at a river gauge), in many cases only mathematical criteria are used. Following the recommendations of Lang et al. (1999), the following approach has been followed: (1) identify an interval of threshold values that maximizes the stability of the POT distribution parameter estimates; and (2) select within this interval the largest threshold with an average of more than 2 peaks per year.

To ensure the stability required by (1), Davison and Smith (1990) and Naden and Bayliss (1993) stated that the mean exceedance above threshold $(x s-s)$ must be a linear function of the threshold $s$ (being $x s$ the mean value of exceedances).

Once the interevent duration and the threshold have been selected, the assessment of future flash floods occurrence can be obtained. The results for each case are presented in Sect. 4 , using the GP distribution fitted to the exceedance series. This distribution is often considered the most adequate for POT modelling (Coles, 2001; Lang et al., 1999, Pickands, 1975). Its parameters have been estimated following the maximum likelihood method.

The assessment of future flash floods will consist of two parts: compare the POT values to determine the future occurrence; and compare the exceedances fitted with the GP distribution to assess the severity of such events. Therefore, the thresholds chosen for the control period will be the same ones used for the future scenarios. This will ease the comparison of flash floods occurrence, but it will imply that the GP distributions will be fitted to a different number of exceedances in each case.

\section{Data}

\subsection{Observations}

The Llobregat watershed is covered by a quite dense measuring instrumentation network, except at the highest altitudes. Meteorological and hydrological daily data comprising precipitation, temperature and discharge have been compiled for the 1980-2008 time period from the Span- ish Meteorological Agency (AEMET) and the Meteorological Service of Catalonia (SMC). Meteorological data cover the whole basin with complete time series. Note that these punctual data have been interpolated at the watershed scale using a spline method. Moreover, a historical database of daily precipitation field is also available (from 1940 to 2010). Based on precipitation patterns computed from weather radar (Velasco-Forereo et al., 2009), this database is characterized by high spatial resolution (cells of $3 \mathrm{~km}$ ) that allows the representation of local variability (Versini, 2012a).

Daily discharge data have also been compiled from the Catalan Water Agency (ACA). Time series from 1980 to 2008 have been analysed and validated for several subbasins. The quality of the data is often poor, with many outliers and gaps.

\subsection{Future scenarios}

For the whole Llobregat River basin, the SMC provided highresolution climate data for the 1971-2100 period (BarreraEscoda and Cunillera, 2011). These data were obtained by means of a dynamical downscaling, nesting the MM5 mesoscale model into the ECHAM5/MPI-OM global simulations developed for the IPCC Fourth Assessment Report (AR4) (IPCC, 2007). The control period is 1971-2000 and the future projections cover the 2001-2100 period for Catalonia. Two emission scenarios from the Special Report on Emission Scenarios (SRES) of the Intergovernmental Panel on Climate Change (IPCC) (Nakićenović and Swart, 2000) have been considered: A2 (severe) and B1 (moderate). The output data have a spatial resolution of $15 \times 15 \mathrm{~km}$, and a temporal resolution of $6 \mathrm{~h}$.

When comparing the MM5 data with the historical database of daily precipitation over the control period, it was observed that the SMC data have a tendency to overestimate precipitation and the seasonal cycle is not correctly represented at the daily timescale. The mean annual bias is $70.6 \mathrm{~mm}$ (12\% of annual-mean observed precipitation) with an annual-mean absolute error of $104.0 \mathrm{~mm}$ for Catalonia when comparing observations with a simulation using the MM5 mesoscale model nested into the ERA40 reanalysis for the control period. On the other hand, annual-mean correlation is 0.60 for Catalonia, and monthly correlations range from 0.40 to 0.65 within the Llobregat River basin. Despite these inaccuracies, the spatial distribution and trends presented in observations at annual scale are well captured by the SMC simulations (Barrera-Escoda and Cunillera, 2011).

In terms of precipitation extremes, Cabello et al. (2011) also studied these data. The main goal of the study was to assess changes in the probability of occurrence of extreme rainfall events for the future periods in the whole Llobregat River basin. This work showed that, at a basin level, the annual maximum daily precipitation values were well described.

Versini et al. (2012b) also compared the same data sets to a historical database of daily precipitation (Versini, 2012a). In 
terms of mean values, similar problems as the ones identified by Barrera-Escoda and Cunillera (2011) were found: SMC data tend to overestimate precipitation values, but the spatial variability is correctly represented; in terms of temperature, the annual cycle is well represented but shows a generalized cold bias.

Due to the several imprecisions found in these data, Versini et al. (2012b) decided to correct these future time series to adapt them to the Llobregat River basin by applying a bias correction (Lenderick et al., 2007).

A multilinear interpolation based on the relationships of the two data sets in the control period was undertaken. In order to properly represent the seasonal variability, this correction was made month by month. Once relationships were found for the historical series, they were applied to correct future data. These corrected precipitation series have been used in the current study as input data of the HBV model.

\section{Application and results}

\subsection{Calibration of $\mathbf{H B V}$}

The HBV model has been separately calibrated on both studied basins. A set of parameters has been adjusted for each basin by comparing daily simulated and observed (when they were available) discharges. In order to simplify the calibration procedure and to reduce the number of parameters to calibrate, different tests were made. For example, $K O$ was fixed to 1 . Finally, the adjustment of the model required the calibration of 6 parameters: $\beta, \mathrm{FC}, K 1, K 2$, UZL and Perc.

Meteorological and hydrological data compiled over the 1980-2008 time period have been used to calibrate and validate the HBV model. It appeared that data quality was quite poor because of the lack of data, numerous outliers, inconsistencies between precipitation and discharge data, bad reproduction of the base flow, etc. For these reasons, only the most recent period (1998-2008) - where data seem to be the more suitable - has been used for calibration.

For both basins, the obtained Nash-Sutcliffe efficiencies (Nash and Sutcliffe, 1970) were quite low and close to 0.3. For the reasons listed above, these values were not sufficient to correctly evaluate the performance of the model. As a consequence, the validation has been focused on the reproduction of peak discharge in terms of amplitude and frequency on the whole time period. In order to obtain an average of more than two peaks per year (see Sect. 2.2), the 90 highest observed and simulated peak discharges have been compared. As shown in Fig. 4, observed and simulated values match very well. They are characterized by a correlation coefficient of 0.97 for Alt Llobregat basin and 0.93 for Anoia basin respectively. These satisfactory results allow us to use the HBV on the future climate series to simulate flash flood intensity for the studied basins.
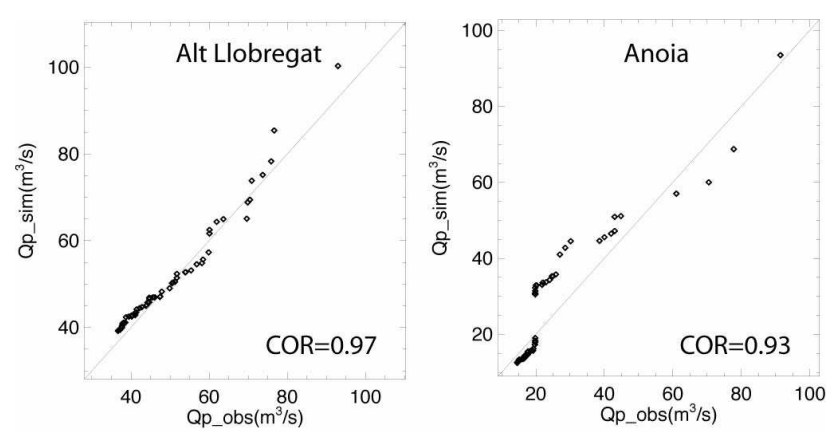

Fig. 4. Comparison between observed and simulated peak discharge for Alt Llobregat basin (on the left) and Anoia basin (on the right).

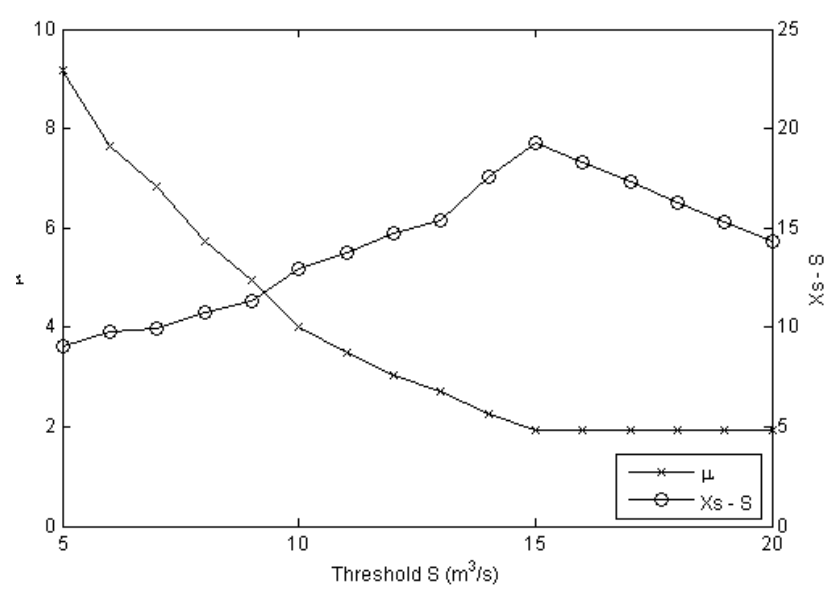

Fig. 5. Threshold selection for the Alt Llobregat basin, using the $x s-$ $s$ values to determine a stable range of $s$, and selecting a threshold with $\mu>2$ peaks per year.

\subsection{Alt Llobregat}

In order to guarantee the independence of the peaks, the autocorrelation factors for lag 1 and lag 2 have been determined. From the results presented in Table 1, it can be concluded that an interevent duration of 7 days must be used to ensure the hypothesis of null autocorrelation between the peaks.

Using this value, the series of peaks are obtained. Figure 5 shows the methodology applied to define the threshold. In the interval of thresholds from 10 to $13 \mathrm{~m}^{3} \mathrm{~s}^{-1}$, the most stable values of $x s-s$ are given. Within this range of possibilities, the highest threshold with $\mu>2$ is selected: $13 \mathrm{~m}^{3} \mathrm{~s}^{-1}$ (which has a value of $\mu=2.72$ ).

Once the interevent duration and the threshold have been selected, the POT analysis can be done, assessing the future flash floods occurrence in the Alt Llobregat sub-basin. Figure 6 presents the simulated discharge values for the control and future periods.

In Table 2, the occurrence of extremes of the future projections is compared to the occurrence in the control period. From these results, it can be concluded that in most cases, 
Table 1. Autocorrelation values for lag 1 and lag 2 of the Alt Llobregat sub-basin, given different interevent duration values.

\begin{tabular}{lrrrrrr}
\hline & \multicolumn{6}{c}{ Interevent duration (days) } \\
\cline { 2 - 7 } & 5 & 6 & 7 & 8 & 9 & 10 \\
\hline $\begin{array}{l}\text { Autocorrelation } \\
\text { coefficient for lag 1 }\end{array}$ & 0.26 & 0.27 & 0.26 & 0.22 & 0.24 & 0.23 \\
$\begin{array}{l}\text { Autocorrelation } \\
\text { coefficient for lag 2 }\end{array}$ & 0.14 & 0.11 & 0.06 & 0.05 & 0.02 & 0.01 \\
$\begin{array}{l}\text { Number of peaks } \\
\begin{array}{l}\text { 95\% confidence } \\
\text { bounds }\end{array}\end{array}$ & 558 & 500 & 453 & 416 & 386 & 363 \\
\hline 0.08 & \pm 0.09 & \pm 0.09 & \pm 0.10 & \pm 0.10 & \pm 0.11 \\
\hline
\end{tabular}

Table 2. Summary of the number of POT of the Alt Llobregat sub-basin for the three study periods and the two scenarios.

\begin{tabular}{|c|c|c|c|c|c|c|c|}
\hline \multicolumn{2}{|c|}{$\begin{array}{c}\text { Control } \\
(1980-2008)\end{array}$} & \multicolumn{3}{|c|}{$\begin{array}{l}\text { Scenario A2 } \\
(2011-2100)\end{array}$} & \multicolumn{3}{|c|}{$\begin{array}{c}\text { Scenario B1 } \\
(2011-2100)\end{array}$} \\
\hline & & 2011-2040 & $2041-2070$ & $2071-2100$ & 2011-2040 & 2041-2070 & $2071-2100$ \\
\hline $\begin{array}{l}\text { Total number } \\
\text { of exceedances }\end{array}$ & 79 & 117 & 98 & 80 & 103 & 101 & 88 \\
\hline$\mu$ & 2.72 & 3.90 & 3.27 & 2.67 & 3.43 & 3.37 & 2.93 \\
\hline
\end{tabular}

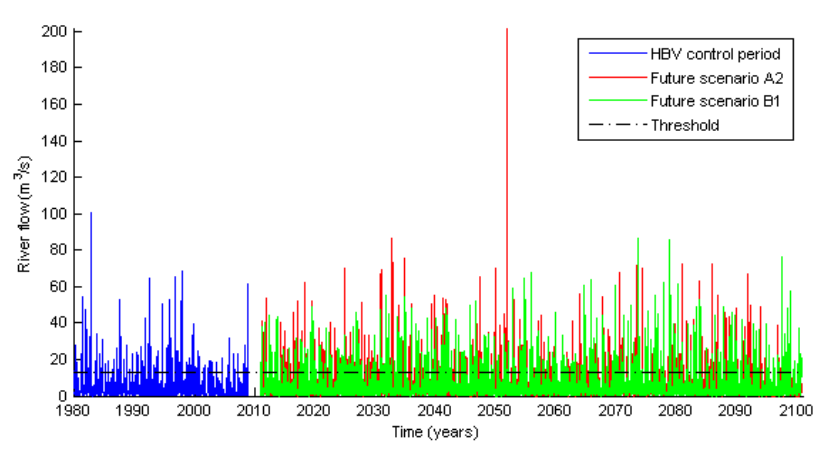

Fig. 6. Time series of the discharge values in the Alt Llobregat sub-basin. The HBV simulations for the control (1980-2008) period (blue) is plotted. The future (2011-2100) discharge series computed with the HBV model for the A2 (red) and B1 (green) SRES scenarios are also presented. The dashed black line represents the threshold of $13 \mathrm{~m}^{3} \mathrm{~s}^{-1}$.

there will be more exceedances of the threshold for the future periods in both scenarios. The only period presenting a significant smaller number of exceedances is the 2071-2100 for the A2 scenario, being $\mu=2.67$ peaks per year.

Figure 7 shows the GP distribution fitted to the exceedances for different periods and scenarios (the estimated GP parameters can be found in Table 5). This figure can be used to assess the intensity of future flood events with respect to the current situation.

For the A2 case (Fig. 7 left), the future scenarios present similar or higher peak discharges than the control period. The 2041-2070 period is the one presenting a more severe situa- tion. On the other hand, B1 scenarios present a diverse situation with respect to the control (Fig. 7 right). It appears that the first (2011-2040) and the second (2041-2070) time periods have lower peak discharges than the control, and the last future period (2071-2100) presents a similar distribution of the peak discharges.

Comparing the results from Table 2 and Fig. 7, it can be seen that for both future scenarios, there is a clear temporal trend: the severity of floods will tend to increase, while the number of floods will tend to decrease with respect to the first future period (2011-2041).

To sum up, it can be concluded that for the Alt Llobregat basin, the flash floods occurrence in the future scenarios would increase. The intensity of such events would also increase in some cases, some others will remain the same, and a few more present smaller peak discharges than the control period. Comparing the A 2 and B1 scenarios, they present similar values of flash floods occurrence, whereas the intensity of these events is higher for scenario A2.

\subsection{Anoia}

As for the Alt Llobregat case, the autocorrelation factors for lag 1 and lag 2 have been calculated and can be seen in Table 3 . For this sub-basin, an interevent duration of 5 days has been selected in order to ensure the hypothesis of null autocorrelation between the peaks.

In Fig. 8, the interval of thresholds presenting the most stable values of $x s-s$ can be identified: from 6 to $10 \mathrm{~m}^{3} \mathrm{~s}^{-1}$. Here, the threshold with $\mu>2$ that is selected is $9 \mathrm{~m}^{3} \mathrm{~s}^{-1}$ (with a value of $\mu=2.10$ ). 

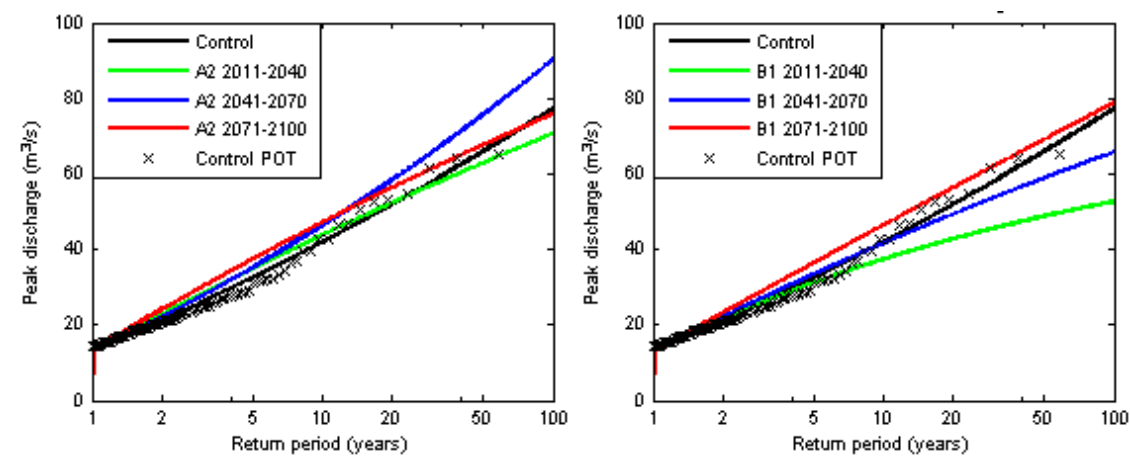

Fig. 7. GP distribution fitted to the POT discharge values of the Alt Llobregat sub-basin for the control (1980-2008) and future periods for the A2 (left) and B1 (right) scenarios.

Table 3. Autocorrelation values for lag 1 and lag 2 of the Anoia sub-basin, given different interevent duration values.

\begin{tabular}{lrrrrrr}
\hline & \multicolumn{5}{c}{ Interevent duration (days) } \\
\cline { 2 - 7 } & 1 & 2 & 3 & 4 & 5 & 6 \\
\hline Autocorrelation coefficient for lag 1 & 0.09 & 0.09 & 0.11 & 0.08 & 0.07 & 0.03 \\
Autocorrelation coefficient for lag 2 & 0.06 & 0.05 & 0.06 & 0.07 & 0.04 & 0.01 \\
Number of peaks & 1042 & 830 & 702 & 612 & 528 & 478 \\
$95 \%$ confidence bounds & \pm 0.06 & \pm 0.07 & \pm 0.08 & \pm 0.08 & \pm 0.09 & \pm 0.09 \\
\hline
\end{tabular}

Table 4. Summary of the number of POT of the Anoia sub-basin for the three study periods and the two scenarios.

\begin{tabular}{lrrrr|rrr}
\hline \multirow{2}{*}{$\begin{array}{c}\text { Control } \\
(1980-2008)\end{array}$} & \multicolumn{3}{c|}{$\begin{array}{c}\text { Scenario A2 } \\
(2011-2100)\end{array}$} & \multicolumn{3}{c}{$\begin{array}{c}\text { Scenario B1 } \\
(2011-2100)\end{array}$} \\
\cline { 2 - 8 } & & $2011-2040$ & $2041-2070$ & $2071-2100$ & $2011-2040$ & $2041-2070$ & $2071-2100$ \\
\hline $\begin{array}{l}\text { Total number } \\
\text { of exceedances } \\
\mu\end{array}$ & 61 & 54 & 51 & 60 & 53 & 61 & 53 \\
\hline
\end{tabular}

As in the previous case, Fig. 9 shows the discharge values for the Anoia sub-basin and the POT values are shown in Table 4. Regarding the occurrence of flash floods, it is observed that the number of POT is considerably smaller in all future periods, being most of the values of $\mu$ below 1.80 .

Regarding peak discharges, most of the curves fitted with the GP distribution (Fig. 10) show that the extremes of the future scenarios present higher values than in the control period (the estimated GP parameters are presented in Table 6). However, it is difficult to identify a common temporal trend for both scenarios: the 2041-2070 period is in both cases the one presenting the highest peak discharge values, while the other time periods behave differently in the two scenarios.

It can be concluded that for the Anoia sub-basin, although the occurrence of flash floods is going to decrease, such events will be more severe.

As a summary, the two studied basins show, in general, an increase of the peak discharge values (Fig. 7 and Fig. 10).
Nevertheless, in terms of the occurrence of flash floods events, they present very different trends. The Alt Llobregat future scenarios present a clear increase of the POT values with respect to the control period. On the other hand, in Anoia the opposite trend is observed: the POT values are smaller than in the control period. Regarding the A2 and B1 scenarios, it is difficult to draw any clear conclusions from the study.

These results are not sufficiently conclusive to draw general trends for the whole Llobregat River basin. Keeping in mind that flash floods are triggered by very localized processes, the two sub-basins studied could present very different trends to some other sub-basins within the Llobregat catchment. Therefore, before undertaking any kind of policy actions or adaptation strategies within this basin, it is recommended to undertake localized studies such as this one to properly assess the future trends. 
Table 5. Parameters of the GP distribution estimates for the Alt Llobregat sub-basin, together with its standard errors.

\begin{tabular}{lrrrr|rrr}
\hline \multicolumn{1}{c}{$\begin{array}{c}\text { Control } \\
(1980-2008)\end{array}$} & \multicolumn{3}{c}{$\begin{array}{c}\text { Scenario A2 } \\
(2011-2100)\end{array}$} & & \multicolumn{3}{c}{$\begin{array}{c}\text { Scenario B1 } \\
(2011-2100)\end{array}$} \\
\cline { 2 - 8 } & & $2011-2040$ & $2041-2070$ & $2071-2100$ & $2011-2040$ & $2041-2070$ & $2071-2100$ \\
\hline $\begin{array}{l}\text { Shape } \\
\text { parameter }(k)\end{array}$ & 0.084 & -0.060 & 0.122 & -0.077 & -0.206 & -0.073 & -0.014 \\
$\begin{array}{l}\text { Standard error } \\
\text { Scale }\end{array}$ & 0.09 & 0.07 & 0.07 & 0.10 & 0.08 & 0.08 & 0.09 \\
$\begin{array}{l}\text { parameter }(\sigma) \\
\text { Standard error }\end{array}$ & 11.419 & 14.347 & 12.517 & 16.204 & 13.314 & 13.526 & 14.788 \\
\hline
\end{tabular}

Table 6. Parameters of the GP distribution estimates for the Anoia sub-basin, together with its standard errors.

\begin{tabular}{|c|c|c|c|c|c|c|c|}
\hline \multicolumn{2}{|c|}{$\begin{array}{c}\text { Control } \\
(1980-2008)\end{array}$} & \multicolumn{3}{|c|}{$\begin{array}{l}\text { Scenario A2 } \\
(2011-2100)\end{array}$} & \multicolumn{3}{|c|}{$\begin{array}{l}\text { Scenario B1 } \\
(2011-2100)\end{array}$} \\
\hline & & 2011-2040 & 2041-2070 & $2071-2100$ & 2011-2040 & 2041-2070 & $2071-2100$ \\
\hline $\begin{array}{l}\text { Shape } \\
\text { parameter }(k)\end{array}$ & 0.547 & 0.578 & 0.477 & 0.465 & 0.722 & 0.884 & 0.823 \\
\hline Standard error & 0.21 & 0.26 & 0.32 & 0.18 & 0.20 & 0.23 & 0.21 \\
\hline $\begin{array}{l}\text { Scale } \\
\text { parameter }(\sigma)\end{array}$ & 7.320 & 9.810 & 14.876 & 8.884 & 4.418 & 6.708 & 4.038 \\
\hline Standard error & 1.74 & 2.75 & 3.25 & 1.94 & 0.97 & 1.63 & 0.88 \\
\hline
\end{tabular}

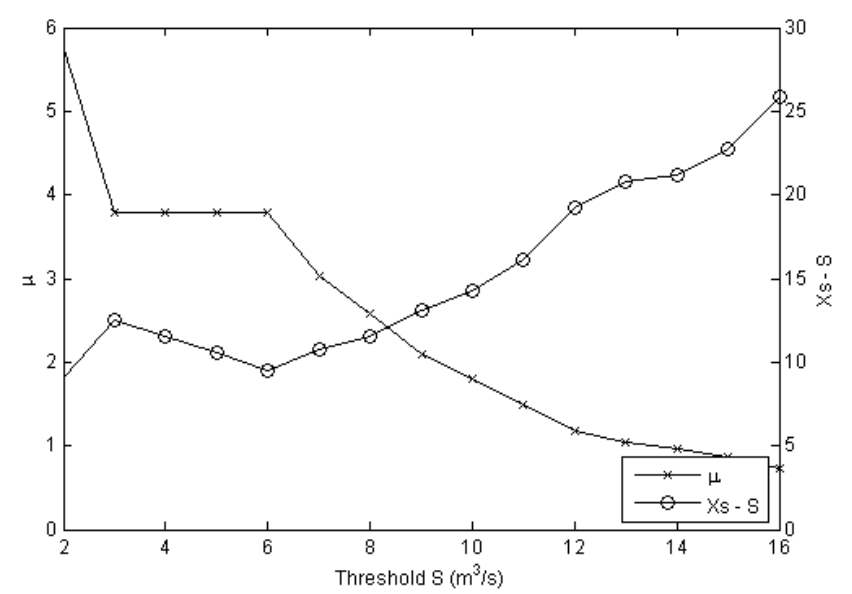

Fig. 8. Threshold selection for the Anoia basin, using the $x s-s$ values to determine a stable range of $s$, and selecting a threshold with $\mu>2$ peaks per year.

\section{Uncertainties}

The uncertainties in assessments of this type are significant (IPCC, 2012). Although it is considered that the choice of the general circulation model is the largest source of uncertainties, some other elements such as the uncertainties from emission scenarios and downscaling methods are also relevant. The choice of hydrological models was found to be relevant but less important (Kay et al., 2009).

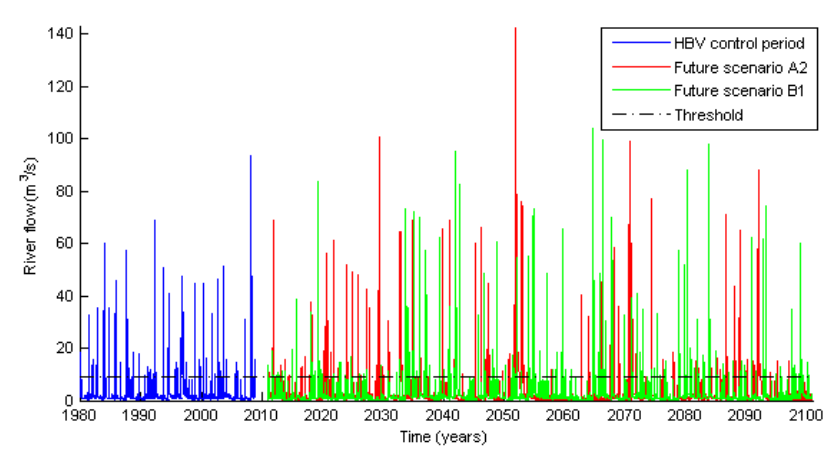

Fig. 9. Time series of the discharge values in the Anoia sub-basin. The HBV simulations for the control (1980-2008) period (blue) is plotted. The future (2011-2100) discharge series computed with the HBV model for the A2 (red) and B1 (green) SRES scenarios are also presented. The dashed black line represents the threshold of $9 \mathrm{~m}^{3} \mathrm{~s}^{-1}$.

In this case, the several steps followed in the methodology imply uncertainties: the HBV hydrological model (calibrated with observations) is fed with climate change data, from which POT series are obtained and then a GP distribution is fitted to them.

In the previous sections, the performances of $\mathrm{HBV}$ and the SMC climate data have been described. The peaks correlations for the HBV calibration presented values of 0.97 and 0.93 for the Alt Llobregat and Anoia sub-basins respectively. 

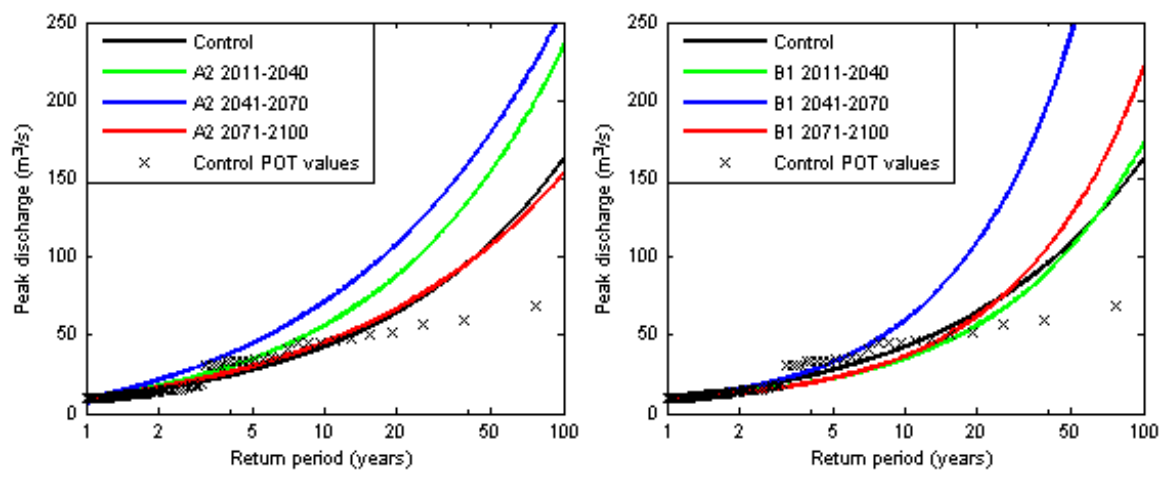

Fig. 10. GP distribution fitted to the POT discharge values of the Anoia sub-basin for the control (1980-2008) and future periods for the A2 (left) and B1 (right) scenarios.

In the whole Llobregat River basin, SMC data presented monthly correlations ranging from 0.40 to 0.65 , which have then been corrected using a bias correction month by month.

In addition, it is worth noting that results from only two scenarios (SRES A2 and B1) fed into one global circulation model and downscaled by one regional climate model have been used. Since the scenarios used might lead to very different results, it is common to simulate a large amount of future time series. Then, the results can be given using quantiles, providing a range with the most plausible situations. As SMC is currently producing more regionalized scenarios for Catalonia, this approach should be used in a future study.

Regarding the POT analysis, the selection of threshold is rather complex and may imply quite different results. That is why the thresholds from the control period have been chosen, maximizing the stability of the POT distribution parameter estimates and keeping a $\mu$ value over 2 events per year.

Finally, the GP distribution has been fitted using a maximum likelihood method. The standard errors of the parameters can be seen in Table 5 and Table 6 .

As it can be seen, there are several uncertainties that are chained in the methodology process. Some of them could be reduced (e.g. by compiling more gauge observations to calibrate the hydrological model) and some of them should be assessed (e.g. using more climate change scenarios). This should be done in a further study to improve the conclusions of the present work.

\section{Conclusions}

A hydrological model has been used to study the future trends of flash floods. This has been done by using the HBV model with the SMC climate change scenarios, and then studying the POT series with a GP distribution.

The future trends of the peak discharges have been assessed by fitting the GP distributions to the POT series. The future trends of occurrence of flash floods have been calcu- lated by comparing the exceedances from future scenarios and the control period, using for all cases the thresholds calculated for the control period.

Despite the uncertainties that appear in the whole process, the results obtained can shed some light on how future flash floods events may occur. For the two sub-basins of the Llobregat River studied, in general, an increase of the peak discharge values is found.

On the other hand, regarding the occurrence of flash floods events, different tendencies are shown for each sub-basin: Alt Llobregat presents a marked increase of the POT values with respect to the control period, whereas Anoia has shown important decreases.

Given the importance of the uncertainties in this study, future work should focus on reducing some of them by (1) using data with finer resolution and that are more localized (so there is no need to undertake bias corrections) and (2) by implementing more future scenarios, using simulations of several global circulation models and regional climate models so a large number of scenarios is obtained and results can be assessed in probabilistic terms.

Acknowledgements. This work has been supported by the European Community Seventh Framework Programme project IMPRINTS (contract number FP7-ENV-2008-1-226555 and website www.imprints-fp7.eu) that copes with the improvement of preparedness and risk management of flash floods and debris flows. The contribution of M. Zappa and K. Liechti on an early version of the paper is greatly acknowledged.

Edited by: M.-C. Llasat

Reviewed by: three anonymous referees 


\section{References}

Akhtar, M., Ahmad, N., and Booij, M. J.: The impact of climate change on the water resources of Hindukush-KarakorumHimalaya region under different glacier coverage scenarios, J. Hydrol., 355, 148-163, doi:10.1016/j.jhydrol.2008.03.015, 2008.

Barrera-Escoda, A. and Cunillera, J.: Climate change projections for Catalonia (NE Iberian Peninsula). Part I: Regional climate modeling, Tethys., 8, 75-87, doi:10.3369/tethys.2011.8.08, 2011.

Barriendos, M., Coeur, D., Lang, M., Llasat, M. C., Naulet, R., Lemaitre, F., and Barrera, A.: Stationarity analysis of historical flood series in France and Spain (14th-20th centuries), Nat. Hazards Earth Syst. Sci., 3, 583-592, doi:10.5194/nhess-3-5832003, 2003.

Bergström, S.: The HBV model - its structure and applications, SMHI Reports RH no. 4, Norrköping, Sweden, 1992.

Cabello, A., Velasco, M., Barredo, J. I., Hurkmans, R. T. W. L., Barrera-Escoda, A., Sempere-Torres, D., and Velasco, D.: Assessment of future scenarios of climate and land-use changes in the IMPRINTS test-bed areas, Environ. Sci. Policy, 14, 884-897, doi:10.1016/j.envsci.2011.03.003, 2011.

Casas, M. C., Cunillera, J., del Amo, X., Herrero, M., Ninyerola, M., Pons, X., Redaño, A., Rius, A., and Rodríguez, R.: Mapes de precipitació màxima diària esperada a Catalunya per a diferents períodes de retorn. Servei Meteorològic de Catalunya, Departament de Medi Ambient i Habitatge, Generalitat de Catalunya, Barcelona, Spain, CD-ROM, 2005.

Coles, S.: An introduction to statistical modeling of extreme values, Springer, UK, 208 pp., 2001.

Collier, C. G.: Flash flood forecasting: What are the limits of predictability. Quart. J. Roy. Meteorol. Soc. 133, 3-23, doi:10.1002/qj.29, 2007.

Creutin, J. D., Borga, M., Lutoff, C., Scolobig, A., Ruin, I., and Créton-Cazanave, L.: Catchment dynamics and social response during flash floods: the potential of radar rainfall monitoring for warning procedures, Meteorol. Appl., 16, 115-125, doi:10.1002/met.128, 2009.

Dankers, R. and Feyen, L.: Flood hazard in Europe in an ensemble of regional climate scenarios, J. Geophys. Res., 114, D16108, doi:10.1029/2008JD011523, 2009.

Davison, A. C. and Smith, R. L.: Models for exceedances over high thresholds, J. R. Stat. Soc. B, 52, 393-442, 1990.

Gaume, E., Livet, M., Desbordes, M., and Villeneuve, J.P.: Hydrologic analysis of the Aude, France, flash flood 12 and 13 November 1999, J. Hydrol., 286, 135-154, doi:10.1016/j.jhydrol.2003.09.015, 2004.

Gaume, E., Bain, V., Bernardara, P., Newinger, O., Barbuc, M., Bateman, A., Blaskovicova, L., Bloschl, G., Borga, M., Dumitrescu, A., Daliakopoulos, I., Garcia, J., Irimescu, A., Kohnova, S., Koutroulis, A., Marchi, L., Matreata, S., Medina, V., Preciso, E., Sempere-Torres, D., Stancalie, G., Szolgay, J., Tsanis, I., Velasco, D., and Viglione, A.: A compilation of data on European flash floods, J. Hydrol., 367, 70-78, doi:10.1016/j.jhydrol.2008.12.028, 2009.

Götzinger, J. and Bárdossy, A.: Comparison of four regionalisation methods for a distributed hydrological model, J. Hydrol., 333, 374-384, doi:10.1016/j.jhydrol.2006.09.008 2007.
IPCC: Climate change 2007: The physical science basis, Cambridge University Press, UK and USA, 996 pp., 2007.

IPCC: Managing the risks of extreme events and disasters to advance climate change adaption (SREX). A Special Report of Working Groups I and II of the Intergovernmental Panel on Climate Change, Cambridge University Press, UK, and USA, 582 pp., 2012.

Jin, X., Xu, C. Y., Zhang, Q., and Chen, Y. D.: Regionalization study of a conceptual hydrological model in Dongjiang basin, south China, Quatern. Int., 208, 129-137, doi:10.1016/j.quaint.2008.08.006, 2009.

Kay, A. L., Davies, H. N., Bell, V. A., and Jones, R. G.: Comparison of uncertainty sources for climate change impacts: flood frequency in England, Climatic Change, 92, 41-63, doi:10.1007/s10584-008-9471-4, 2009.

Kundzewicz, Z. W., Mata, L. J., Arnell, N. W., Döll, P., Kabat, P., Jiménez, B., Miller, K. A., Oki, T., Sen, Z., and Shiklomanov, I. A.: Freshwater resources and their management. In: Climate Change 2007: Impacts, Adaptation and Vulnerability. Contribution of Working Group II to the Fourth Assessment Report of the Intergovernmental Panel on Climate Change, Cambridge University Press, Cambridge, UK, 173-210, 2007.

Kundzewicz, Z. W. and IAHS: Changes in flood risk in Europe, International Association of Hydrological Sciences, US, 516 pp., 2012.

Lang, M., Ouarda, T. B. M. J., and Bobée, B.: Towards operational guidelines for over-threshold modeling. J. Hydrol., 225, 103117, 1999.

Leander, R. and Buishand, T. A.: Resampling of regional climate model output for the simulation of extreme river flows, J. Hydrol., 332, 487-496, doi:10.1016/j.jhydrol.2006.08.006, 2007.

Lenderink, G., Buishand, A., and van Deursen, W.: Estimates of future discharges of the river Rhine using two scenario methodologies: direct versus delta approach, Hydrol. Earth Syst. Sci., 11, 1145-1159, doi:10.5194/hess-11-1145-2007, 2007.

Lidén, R. and Harlin, J.: Analysis of conceptual rainfall-runoff modelling performance in different climates, J. Hydrol., 238, 231247, 2000.

Llasat, M. C., Rigo, T., and Barriendos, M.: The "Montserrat-2000" flash-flood event: a comparison with the floods that have occurred in the northeastern Iberian Peninsula since the 14th century, Int. J. Climatol., 23, 453-469, doi:10.1002/joc.888, 2003.

Llasat, M. C., Barriendos, M., Barrera, A., and Rigo, T.: Floods in Catalonia (NE Spain) since the 14th century. Climatological and meteorological aspects from historical documentary sources and old instrumental records, J. Hydrol., 313, 32-47, doi:10.1016/j.jhydrol.2005.02.004, 2005.

López Bustos, A.: Resumen y conclusiones de los estudios sobre avenidas del Vallés en 1962, Instituto de Hidrología, Technical Report, Madrid, 1964.

Marchi, L., Borga, M., Preciso, E., and Gaume, E.: Characterisation of selected extreme flash floods in Europe and implications for flood risk management, J. Hydrol., 394, 118-133, 2010.

Martín-Vide, J. P., Ninyerola, D., Bateman, A., Navarro, A., and Velasco, E.: Runoff and sediment transport in a torrential ephemeral stream of the Mediterranean coast, J. Hydrol., 225, 118-129, doi:10.1016/j.jhydrol.2010.07.017, 1999.

Merritt, W. S., Alila, Y., Barton, M., Taylor, B., Cohen, S., and Neilsen, D.: Hydrologic response to scenarios of climate change 
in sub watersheds of the Okanagan basin, British Columbia, J. Hydrol., 326, 79-108, doi:10.1016/j.jhydrol.2005.10.025, 2006.

Miquel, J.: Guide pratique d'estimation des probabilités de crue, Eyrolles, France, 160 pp., 1984.

Naden, P. S. and Bayliss, A. C.: Flood estimation: peakoverthreshold techniques. MAFF Conf. of River and Coastal Engineers, University of Loughborough, UK, 5-7 July, 9-18 pp., 1993.

Nakićenović, N. and Swart, R.: Special Report on Emissions Scenarios, Intergovernmental Panel on Climate Change (IPCC), Cambridge University Press, Cambridge, UK, 570 pp., 2000.

Nash, J. E. and Sutcliffe, J. V.: River flow forecasting through conceptual models part I - A discussion of principles, J. Hydrol., 10, 282-290, 1970.

Pickands, J.: Statistical inference using extreme order statistics, Ann. Stat., 3, 119-131, 1975.

Raff, D. A., Pruitt, T., and Brekke, L. D.: A framework for assessing flood frequency based on climate projection information, Hydrol. Earth Syst. Sci., 13, 2119-2136, doi:10.5194/hess-13-21192009, 2009.

Steele-Dunne, S., Lynch, P., McGrath, R., Semmler, T., Wang, S., Hanafin, J., and Nolan, P.: The impacts of climate change on hydrology in Ireland, J. Hydrol., 356, 28-45, doi:10.1016/j.jhydrol.2008.03.025, 2008.

Thorndycraft, V. R., Benito, G., Rico, M., Sopeña, A., Sánchez-Moya, Y., and Casas, A.: A long-term flood discharge record derived from slackwater flood deposits of the Llobregat River, NE Spain, J. Hydrol., 313, 16-31, doi:10.1016/j.jhydrol.2005.02.003, 2005.

Todorovic, P.: Stochastic models of floods. Water Resour. Res., 14, 345-356, 1978.

Turco, M. and Llasat, M. C.: Trends in indices of daily precipitation extremes in Catalonia (NE Spain), 1951-2003, Nat. Hazards Earth Syst. Sci., 11, 3213-3226, doi:10.5194/nhess-11-32132011, 2011.
Uhlenbrook, S. and Sieber, A.: On the value of experimental data to reduce the prediction uncertainty of a processoriented catchment model, Environ. Modell Softw., 20, 19-32, doi:10.1016/j.envsoft.2003.12.006, 2005.

van Pelt, S. C., Kabat, P., ter Maat, H. W., van den Hurk, B. J. J. M., and Weerts, A. H.: Discharge simulations performed with a hydrological model using bias corrected regional climate model input, Hydrol. Earth Syst. Sci., 13, 2387-2397, doi:10.5194/hess13-2387-2009, 2009.

Velasco-Forero, C. A., Sempere-Torres, D., Cassiraga, E. F., and Gómez-Hernández, J. J.: A non-parametric automatic blending methodology to estimate rainfall fields from rain gauge and radar data, Adv. Water Resour., 32, 986-1002, doi:10.1016/j.advwatres.2008.10.004, 2009.

Versini, P. A.: Use of radar rainfall estimates and forecasts to prevent flash flood in real time by using a road inundation warning system, J. Hydrol., 416, 157-170, doi:10.1016/j.jhydrol.2011.11.048, 2012.

Versini, P. A., Berenguer, M., and Sempere-Torres, D.: Reconstruction of historical precipitation based on radar fields, application on Catalonia region (Spain), EGU General Assembly 2012, Vienna, Austria, 2012a.

Versini, P. A., Pouget, L., Mc Ennis, S., Guiu, R., Sempere-Torres, D., and Escaler, I.: Climate change impact on water resources Example of an anthropized basin (Llobregat, Spain), EGU General Assembly 2012, Vienna, Austria, 2012b.

Younis, J., Anquetin, S., and Thielen, J.: The benefit of highresolution operational weather forecasts for flash flood warning, Hydrol. Earth Syst. Sci., 12, 1039-1051, doi:10.5194/hess-121039-2008, 2008.

Zhang, X. and Lindström, G.: Development of an automatic calibration scheme for the HBV hydrological model, Hydrol. Process., 11, 1671-1682, 1997. 